\title{
Democratization and The Politics of Conflict Resolution in Indonesia: Institutional Analysis of East Timor Referendum in 1999
}

\author{
Ali Munhanif \\ \{ali.munhanif@uinjkt.ac.id\} \\ Universitas Islam Negeri Syarif Hidayatullah Jakarta, Indonesia
}

\begin{abstract}
Most of the literature on post-conflict elections examines the process of utilizing elections to resolve intra-state conflict. Such topics as democratization, power sharing, and political participation have occupied important place in works on postconflict elections, especially those related to ceasing hostilities in civil war. This paper seeks to explore post-conflict elections which are concerned with self-determination. The East Timor referendum in Indonesia provides an illuminating case in the exploration of post-conflict elections that have a bifurcated motive-to resolve the problem of the intrastate conflict and to secede from the Indonesian Republic. Using historical-institutional analysis of this particular case of referendum, this paper provides an illuminating example that the nature of East Timor referendum-based balloting may be similar to many cases of post-conflict election, nonetheless the motives and actors involved in the conflict are different. As a result, the approach for the international community in providing assistance and supports necessitates differences as well, especially in relation to the presence of international peace keeping forces on the ground when the balloting was held. This article seeks to contribute to literature on the study of democratic transition that intersects with the problem of secessionist politics in the developing countries.
\end{abstract}

Keywords: East Timor, Referendum, Self-determination, Social Movement, Democratic Transitions

\section{Introduction}

Recent events in world politics reveal to us that referendum has increasingly become new way of thinking to resolve intra-state conflict. Such an international norm has become widespread as exemplified in Quebec, Canada (1996), Ireland, Great Britain (2000), South Sudan, Sudan (2010), Scotland, Great Britain (2013), Krimea, Russia (2011), Kurdistan, Iraq (2016), Puerto Rico, USA (2014), Catalonia, Spain (2017) and, Great Britain's decision to exit from the European Union (2016). The extent to which the secessionist states or regions secede vary and are dependent greatly on whether the seceding organizations are able to ascertain their fellows that democratic solution for self-determination is the best voice for them. But my question is rather, under what conditions a nation-state may hold referendum for region or community to resolve their territorial conflict?

Most of the literature on referendum examines the process of utilizing elections to resolve intra-state conflict. Such topics as democratization, power sharing, and participation occupy 
an important place in works on post-conflict elections, especially those related to ceasing hostilities in a civil war [1][2]. Rarely does research on post-conflict elections explore referendum concerned with self-determination. The East Timor referendum provides an illuminating case in the exploration of post-conflict elections that have a bifurcated motiveto end the civil war and to separate from the Indonesian Republic. My argument is straightforward: although the nature of self-determination-based balloting is similar to many cases of post-conflict elections, the motives and actors involved in the conflict, however, are different. As a result, this necessitates a different approach for the international community in providing assistance.

This paper seeks to explain two remarkable events: the relative success of the East Timor referendum process and the failure of security forces to handle mass violence in the postreferendum balloting. I argue that the factors that seem to have driven the spread of violence after the referendum are not solely reliant the political actors who were involved in the conflict, but rather, the Indonesian military who wished to maintain East Timor under its control. When the East Timor referendum was held, Jakarta was undergoing a crucial process of democratic transition. Yet, certain generals in armed forces resisted the wave of change that swept throughout the country. These generals were reluctant to surrender control over East Timor. Losing the referendum wounded the military, which was unable to maintain territorial integrity as a result of international pressure. The campaign of destruction and displacement after the referendum was not a declaration to return to war, as in other cases such as in Angola, Serria Lone and Cambodia, but as a punishment for those who voted for change and the establishment of the independent state of East Timor.

Embedded in the issues of post-referendum violence is, however, international web of pressure to call for democratic balloting in resolving intra-state conflict. The UN mission for humanitarian intervention in East Timor demonstrates how the international community can develop a pressure web to help territory of a given state exit peacefully. Scrutinizing the East Timor crisis in a post-vote situation, one may pose some questions: How do these different factors come together? Related to this question, is the issue of agency, for example who has the authority to take action and based on what moral principles. What happened in early September 1999 in East Timor showed various instruments - including strength - that the international community had influence on a strong sovereign state like Indonesia to allow its territory in East Timor to come out peacefully. However, when the risk of violence is my opinion that when the Indonesian security forces failed to control the violence involving militias in East Timor, the country's sovereignty became increasingly confined by the norms of humanitarian responsibility.

\section{East Timor, Indonesia and Secessionist Movements}

When Indonesia invaded East Timor in December 1975, in fact the area was a relatively less well-received area of Portuguese colonialism. As a result, in terms of economic and social development did not experience significant development. The colonial system deliberately maintains the local socio-political structure, including the liurai, the traditional village heads[3]. The area was divided up based on various cultural groups that spoke Portuguese in 1975, while a significant portion of the population spoke Tetum, the local lingua franca. In the 1960s, nationalist elites emerged echoing patterns found in many other parts of the colonial world. When the coup d'état occurred in Lisbon, Portugal, which showed signs of the end of 
colonial rule in 1974, in East Timor several organizations emerged, such as the Democratic Union of Timorese (UDT), the Social Democratic of Timorese (ASDT), and the Popular Democratic Association of Timorese (Apodeti) which has the same goal, namely for independence or autonomy in East Timor. [3][4].

However, the various organizations have differences in terms of social basis and ultimate goals. UDT, for example, is an organization that has a more conservative basis and is rooted in administrative officials and small Catholic landowners. This organization voiced federation with Portugal during the transition period to full independence. ASDT emerged as a more vocal organization in its rejection of Portuguese rule. He urged that the transition could take place more quickly towards independence. While Apodeti is an organization formed based on the principle of integration with the status of autonomy in the sovereignty of Indonesia. On the principle of integration, Apodeti received support and was promoted by Indonesian agents.[5][6].

Initially, UDT was the most popular organization, but was quickly defeated by the progressive ASDT which in September 1974 was renamed the Revolutionary Front of Independent East Timor (Fretilin).[4]. Fretilin launched literacy campaigns and provided agricultural technical assistance in rural areas through various economic and social intiatives. The short Fretilin administration received strong support from the community. This was stated by several Australian MPs who visited the region. According to James Dunn, a former Australian consul and longtime observer in Dili, various forms of administrative shortage under Fretilin did not diminish the support of citizens. Fretilin enjoyed broad support including from UDT supporters.[3]. Fretilin's aims and programs were able to manage Timorese grievances and respond in ways that UDT and Apodeti were unable to do.

Fretilin declared independence when Indonesia began a military invasion. To further assert itself and to get support from other countries, Fretilin proclaimed Timor Leste's independence on 28 November 1975. This political development occurred after the Portuguese failed to negotiate a settlement of their colonial problems with the East Timorese. The steps taken by the Indonesian military with the large-scale invasion of Dili on 7 December 1975 were inseparable from support through a declaration from UDT and Apodeti which stated they were willing to fully integrate with Indonesia. Upon the invasion carried out by the Indonesian military, Fretilin leaders and their supporters fled to the mountains and waged a long period of resistance against the Indonesian military.[5][4][7].

The control held by the Indonesian military over the Dili area encouraged him to expand his invasion to areas controlled by Fretilin. At the end of December 1975, the Indonesian military in large numbers (around 15,000-20,000) terrorized the population with brutal shootings, looting, and persecution. This was done because Fretilin's presence gained widespread support from the villagers, making it difficult for the Indonesian military to cripple its enemies.[6]. Lopez da Cruz, the deputy governor of East Timor appointed by the Indonesian government from 1976-1980, estimated that by February 1976 no less than 60,000 people had been killed in the Indonesian military war with Fretilin. Da Cruz acknowledged that the Indonesian military invasion of East Timor brought "excesses" to the Fretilin suspects. In its development, the Indonesian government continued to mobilize its military to East Timor. No less than 40,000 Indonesian troops were sent to East Timor to exterminate the Fretilin group.[3]. By carrying out massive attacks through heavy bombing, the Indonesian military burned down fields and forced local residents into more restricted areas so that they were forced. Other control efforts undertaken by the Indonesian military are forcing migration, imprisonment and relocation to camps. A report by USAID in 1982 stated that nearly 300,000 people were moved in 150 camps. The report also mentioned that the camps were suggested as 
settlements for development, when in fact it was to control and guarantee security.[7].

In response to this growing humanitarian crisis in East Timor, the UN issued a number of resolutions condemning the Indonesian invasion and demanding an immediate and full troop withdrawal. This was reflected in the Security Council Resolution 389, April 22, 1976, called for Indonesia "to withdraw without delay all its forces from East Timor" [8][9]. This resolution demonstrated the UN's position that East Timor's sovereignty did not belong to Indonesia. Jakarta ignored the statements and on December 17 announced a provisional government in Dili headed by an Apodeti official and the UDT's Lopez Da Cruz. In May 1976, the interim administration convened a People's Assembly in which 37 hand-picked delegates voted for integration with Indonesia. Arguing that this vote constituted a "free and willing act of Timorese self-determination", Suharto declared East Timor to be Indonesia's twenty-seventh province on July 17, 1976 [8].

Nevertheless, throughout the post-Indonesian invasion period, most Western countries, especially the US, UK, and Australia, did everything they could to contradict the UN's stance. The US ambassador to UN during the Ford administration, Daniel P. Moynohan, mentioned his country's position that "the State Department desired that the United Nations prove utterly ineffective in whatever measures it undertook"; a task that, by his own admission, he carried out "with no inconsiderable success"[10][11]. Australia, too, although formally still maintained the "Jakarta first policy", was equally at odds with the UN resolution. It is reported that the Australian representative to the UN stated in 1979 that, "Australia believed the question of the decolonisation of East Timor to have been resolved"[8][12]. Australia's attitude towards the Indonesian invasion of East Timor not only strengthened the legitimacy of the Indonesian occupation of East Timor, but also Australia used its influence to counter criticism and provide support for Indonesia at the United Nations. This is as illustrated by Richard Leaver that Australia's support for Indonesian Colonization of East Timor was followed by de facto and de jure recognition of Indonesian sovereignty.[8][13].

The attitudes of major Western countries toward the East Timor issue began to change directions in the early 1990s, following the collapse of communist regimes in the Soviet Union and Eastern Europe. The Dili incident in November 1991 marked the turning point Indonesian forces fired into a protest march that was mourning the death of pro-independence activists, killing and wounding hundreds of civilians. As a result, pressure mounted for Western governments to criticize the Indonesian occupation. [12][14][10]. But, as long as Suharto remained in power there was little prospect of change in the status of East Timor. It was only after the resignation of Suharto in May 1998 in favour of his civilian vice President B.J. Habibie that real change became possible. Expressing his intention to move Indonesia towards a true pluralist democratic government, Habibie was committed to finding a genuine settlement to the East Timor conflict as quickly as possible. An ensuing path of national and international diplomacy conducted through his foreign minister, Ali Alatas, culminated with the unexpected decision in January 1999 to let the East Timorese decide for themselves whether they wished to remain in Indonesia with special autonomy or chose independence [13][7].

\section{Democratization and the International Pressure}

The policy taken by President Habibie to conduct a referendum for the people of East Timor to choose between special and independent autonomy became the path for significant 
transformation in policies related to East Timor. Since 1982 Indonesia has begun UNsponsored talks to resolve the East Timor problem by giving greater autonomy possibilities. During the Habibie era, efforts to resolve the East Timor problem increasingly provided wider space for the aspirations of the East Timorese people. Even President Habibie promised that if the people of East Timor rejected the autonomy proposal, he would ask the Indonesian People's Consultative Assembly (MPR RI) to grant independence.[13][9][15].

On May 5, an agreement was made by the UN, Portugal and Indonesia to allow an UNsupervised referendum. However, a key and controversial element in the agreement was the role of the Indonesian armed force (Tentara National Indonesia, TNI) in providing security and ensuring order [9][15].

The consequences of this decision, as we will see, are disasters. The pre-ballot situation showed the tensions experienced by the UN Mission in East Timor (UNAMET), which was mandated to hold elections. They faced pro-integration militias who tried to intimidate and disrupt the popular consultation process. September 4, 1999 the disaster came, which was not long after the results of the referendum were announced. Pro-Indonesian militias supported by the TNI began to threaten and kill key figures from civil society in the independence movement.[15][9]. As the violence spiralled out of control, it became obvious for the international community that peacekeeping forces were needed to end the violence in East Timor.

To compare the UN mission in East Timor and in Cambodia, one may find that the two UN missions are the same. Regional politics and recent history, as well as the political, social and cultural features each country shaped the missions. The main difference between the two missions lies in their size, but the composition, deployment and modus operandi were similar [1][16]. The UN mission in Cambodia was two-phased, first an advance mission (UNAMIC, the UN Advance Mission in Cambodia) in November 1991 was expanded in March 1992 into a much larger peace-keeping operation (UNTAC, the UN Transitional Authority in Cambodia). The later mission comprised seven components including administration, electoral, repatriation and rehabilitation. The June-September 1998 mission in East Timor began as an assistance mission (UNAMET, the UN Assistance Mission in East Timor). This mission was followed by a peace-keeping operation (UNTAET, the UN Transitional administration in East Timor), also encompassing administration, electoral and reparation and rehabilitation tasks. And here is the difference: while UNTAET and the two missions in Cambodia were peace-keeping operations, UNAMET was an electoral assistance mission preceding a peace-keeping operation. The International Force in East Timor (INTERFET) was a peace-enforcing operation, mandated to restore peace and security, to protect UNAMET, and facilitate humanitarian assistance before the arrival of the peace-keeping force, UNTAET [16].

The UNAMET had the same primary tasks as the UNTAC to organize and conduct a ballot. Yet, they have differences in terms of security arrangements and size: UNAMET registered 450,000 voters for a referendum with two protagonists - the pro-autonomy under Indonesian sovereignty and pro-independence groups. UNTAC, on the other hand, arranged elections contested by 20 parties with almost 4.7 million voters. However, although the voting population in East Timor was less than on-tenth that of Cambodia, UNAMET's budget (\$51 million) and number of personnel (988) was far less than one-tenth that of UNTAC (\$1.6 billion and 22,000 personnel) [13].

It is worth noting the UNAMET's administrative tasks of controlling transitional process in the East Timor referendum. In theory, based on the UN experience in peacekeeping operations in post-conflict elections, the Transitional Administration in East Timor included the objects of disarm, repatriate, rebuild and control. As far as the demobilization processes 
was concerned, UNAMET personnel were unarmed and relied on the Indonesian police to provide security. Under the May 5 tripartite agreement, it is said that during the UNAMET operation to prepare the referendum (June-September) the Indonesian security forces were responsible for maintaining "a secure environment divided of violence or other forms of intimidation"[13]. It soon became clear that, since the arrival of UNAMET, the Indonesian police failed to fulfill this task.

The referendum preparations started very quickly after the Indonesian government in Jakarta gave security assurances in mid-May 1999. But as the UNAMET personnel began to make pre-electoral assessments, the people in East Timor immediately were divided into two political camps: pro-Indonesian integration, organized under several names, and proindependence groups operating under the umbrella organization CNRT, National Council of Timorese Resistance, with its armed wing, Falintil[6][13].

The situation taking place in East Timor faces a very unbalanced poll. Pro-Indonesian militias are very dominant, so the presence of international security forces, as seen by UNAMET personnel in East Timor, is very much needed so that the popular consultation will proceed peacefully, freely and fairly. The presence of pro-Indonesian armed militias who roam free from law throughout the territory of East Timor poses a threat to the continuation of a fair referendum.[17]. The militia groups involved in acts of violence and terror against ordinary people were armed, trained and fully supported by the Indonesian security forces, the TNI. In many cases, TNI soldiers themselves were militia members. The TNI's reason for supporting the militias was one thing rather simple, namely that they wanted to terrorize the population to accept a sustainable Indonesian government, while distancing themselves from responsibility for violence. [6].

A closer examination of the Indonesian security structure during the New Order government demonstrates that the involvement of pro-Indonesian militias in the violence preceding the referendum was unavoidable. It was a part of the defense-security doctrine of Indonesian political system under New Order military regime. Historically speaking, the use of ordinary people such as homeless, gangsters, and other informal units of armed people in cities, was a part of the military strategy during revolutionary war against the Dutch in 19451949. In dealing with East Timor, Indonesian authorities have always dealt with the problem of two opposing sides of East Timorese, and since the invasion in 1975, they have exploited rivalries [18][6]. The existence of militias is part of the Indonesian military strategy in occupying East Timor. However, since late 1998 along with the birth of the reform era and the strong will of the people of East Timor to free themselves from Indonesian rule, the existence of the militias was strengthened by attracting East Timorese youths to join. Each district has its own militia. [6]. In early April 1999, for example, militia groups that were already operating in several districts, such as the Ermera district, joined together and expanded their network to become part of what was called the DarahIntegrasi (Blood Integration) based in Ermera.[6].

\section{Democratic Balloting that Turns to Violence}

The polling took place at 200 polling stations throughout East Timor. More than 97 percent of registered voters participated in the referendum. It is likely that most voters were familiar with the CNRT and pro-Indonesia symbols which appeared in every polling station. Voters were given ballot papers that asked two questions: 'Do you ACCEPT the proposed 
autonomy for East Timor within the Unitary State of the Republic of Indonesia?' or 'Do you REJECT the proposed special autonomy for East Timor, leading to East Timor's separation from Indonesia?'. The questions were translated into four languages, and the Indonesian and CNRT flags were drawn in color alongside the two choices [6].

According to international observers, the voting itself was fair. The UNAMET attitude toward both pro-Indonesia and pro-independence groups was also balanced [13][17]. However, the evening after the ballot, violence began to occur. In the beginning, incidents took place in districts that had been the most active pro-independence strongholds. The militias burnt houses of CNRT leaders and searched for people who were accused as having voted for independence [16]. This attitude was not surprising. It was a mounting indication that the CNRT would win, and alarming statements made by East Timorese government officials. Governor AbilioSaores, for instance, had suggested on the day of referendum that the territory would be partitioned if the vote called for independence [16]. The development of international diplomacy that put Indonesia under sustained and coordinated pressure from the international community also contributed to the increasing tensions in the post-vote situation. Undoubtedly, the most significant factor influencing the attitude of pro-Indonesia integration groups were a miscalculation over the likely referendum result. The final intelligence reports to Habibie and Minister of Foreign Affairs, Ali Alatas, estimated that between 55 and 60 percent of East Timorese would vote for autonomy under Indonesia [13].

The disaster reached its climax on September 4, 1999 immediately after the results of referendum were announced in New York. The UN Secretary General, Kofi Annan, announced: only 94,388 (21.5 percent) in favour and 344,580 (78 percent) against the proposed special autonomy. TNI-sponsored pro-integrationist militias began killing key figures in the independence movements and terrorizing civilians [15][9]. A Report published by the UN and Indonesia's National Human Rights Commission estimated that in the one week of violence 70 percent of the buildings, including shops, offices and homes in East Timor districts, had been destroyed [9]. The level of damage in Liquica and Maliana was estimated at 80 percent. Vital infrastructure was crippled, leaving Dili and major towns without running water, electricity or telephones.

A Report of the Security Council mission to East Timor estimated that over 1,000 lives had been lost in the riots [7]. The report also indicated that Militia activities were organized and supported by TNI factions. On 8 September thousands of Timorese were driven from their burned houses and fled to the hills; hundreds of pro-independence supporters were killed; UN officials and journalists were subjected to threats and violence; and around 3,000 refugees per hour forced to move to West Timor, Indonesia. Although President Habibie gave guarantees that the Indonesian military and police would restore the situation in East Timor quickly, conditions on the ground were far from expectations. Under these conditions, the international security community tried to end the violence that occurred through the deployment of peacekeepers in East Timor [15][13]. As the violence spiralled out of control, it become obvious for the international community that humanitarian operation to end the East Timor crisis was unavoidable.

Since drafted, the U.N. intervention in East Timor is unique in character. Under the terms of the organization 's charter, the international intervention in East Timor is not a "Chapter 7" intervention, which regulates the possibility of a state under UN mandate to intervene with another state. In this regard, the U.N. presence was by invitation, and the authority it could exercise was limited by its mandate. The Indonesian police (POLRI) remained responsible for security in East Timor for the duration of the UN consultation [9]. Significantly, UN police personnel would be confined to their role advisers. Under such circumstances, the UN 
intervention in East Timor was operating under the provisions of "Chapter 6", that is, "through acceptance by all the parties concerned"[13][14].

The intervention of the United Nations humanitarian operation in East Timor in the postCold War era was a form of success compared to other humanitarian operands in other countries. UN humanitarian interventions in Somalia, Albania and Kosovo, show a mismatch between military facilities and the humanitarian objectives of the "Mission Complete". UN intervention in East Timor departs from the tragedy that occurred after the referendum. Since the beginning of the referendum case which resulted in the separation of East Timor from the unitary state of Indonesia, it was feared that it would be a trigger for the emergence of separatism in other regions as happened in the Balkan countries. Therefore, from the beginning the UN Security Council has committed to effectively resolve the East Timor crisis in order to prevent the spread of violence and humanitarian crises in other regions. [9]. What is difficult to understand is had the Habibie government consented to the deployment of an international intervention. It seems that Indonesia still had strong reservations about its national sovereignty. This sensitivity to Indonesia's concerns and interests was reflected in the draft of the UN Resolution 1264.

It is clear that the Council wants to emphasize the importance of cooperation between Indonesia and the United Nations in forming a multinational force. As such, the resolution reinforces the importance of respecting Indonesia's sovereignty and territorial integrity, despite the fact that Australia is a country that recognizes Indonesian sovereignty unconditionally over East Timor. [15][9]. Habibie firmly reiterated this position in his discussion with Kofi Annan on September 10. As a new regime in Indonesia, Habibie framed the debate of East Timor issue in the wider context of maintaining the territorial integrity of Indonesia. More specifically, he consistently warned that any move from the international community to intervene Indonesian domestic affairs would inevitably provoke secessionist demands elsewhere, such as Aceh and West Papua [4]. However, Habibie's foreign policy certainly looks unreachable, due to the obstacles faced by the regime. Within a few days, President Habibie had made a total change from initially wanting to mobilize Indonesian military power in the context of peace in East Timor, but eventually accepted offers of military assistance from outside. How did the policy change occur?

The key factor, which contributed to this change, was a threat levelled by the international community in relation to the domestic political issues faced by the Indonesian government since the economic crisis in 1997. In this situation, the international community can force Jakarta to accept an international force that has proven unable to mobilize when such a force might prevent the escalation of violence that ensues. There are two sets of pressures that have succeeded in getting Indonesia to accept international intervention in East Timor. First, there is a coercive impact from the withdrawal of IMF and World Bank loans, and the end of military assistance. Second, there is the moral pressure of Indonesia which acts as an international pariah.

That there is a very strong influence of international pressure on Indonesian policy can be seen from the orders of US President Clinton who ordered the suspension of all military cooperation programs with Indonesia. In other words, if Indonesia fails to deal with violence in East Timor, it requires the participation of the international community to help restore security.[19][20]. The impact of national policy on international cooperation can be seen from the US decision to postpone military cooperation with Indonesia, which was then followed by New Zealand. Even the European Union is increasingly narrowing the space for Indonesia with its decision to impose an arms embargo on Indonesia [19][20][21].The threat of military sanctions is one way to put pressure on the Habibie government. However, the most effective 
threat to influence a country's policies, in this case Indonesia, is the threat of financial sanctions. In this case, Clinton urged to prevent Indonesia from obtaining much needed IMF and World Bank loans. According to Clinton the success of Indonesia's future depends on how Indonesia resolves the present, not the past.[19][15][21]

The strength of the political economy in the context of intervening in a country's policies can be seen from Indonesia's powerlessness against IMF and World Bank pressure which forced Indonesia to accept international peacekeeping forces. The IMF took steps to reduce loans shortly after Clinton called for an reduction in international loans. In addition, they postponed planned visits to review Indonesia's progress, even though it was very much needed before the next installment of US \$ 450 million could be approved. As is known, overall, the rescue package provided by the IMF to Indonesia is $\$ 12.3$ billion and $\$ 2.3$ billion must still be given. Five days later, the World Bank reportedly canceled a $\$ 1$ billion aid program for Indonesia. This step was taken by the World Bank by linking to the government's seriousness in ending violence in East Timor. This step can be understood not merely as a response to a banking scandal, but this is more than just an excuse because of Australia. James Wolfensohn, then president of the World Bank, the previous week urged President Habibie that the government respect the results of the referendum. The economic threat from the monetary crisis in 1997 and the threat of financial support from the IMF and the World Bank sent a clear signal to investors that Indonesia is a country that is not good for investment. This fact in itself has an impact on currency instability [19][13]. Recognizing the worsening crisis in East Timor, President Habibie finally on September 12, 1999 approved the placement of multinational forces. This decision weighed heavily on General Wiranto, as minister of defense and security/commander of the Indonesian army, and this may explain why the TNI was prepared to back its political masters [9].

By all accounts, the INTERFET had done its task in restoring order, putting a swift end to militia violence, and managing the delicate task of getting the TNI out of the territory by the end of October. The pro-integrationists also declined their demand to reject the referendum results. Militia leaders withdrew from East Timor and join refugee camps in West Timor Indonesia. Despite frantic efforts by Indonesian officials in Jakarta and the TNI's persuasion to militia leaders to end the violence, resumption of conflict with pro-independence CNRT could be avoided. The Timorese, who experienced a 24-year civil war under Indonesian rule, changed under UN authority which would control the gradual transfer of power to an independent East Timor government. Habibie, as president who issued the referendum policy, was strongly condemned by the majority of the Indonesian people for losing East Timor and he was defeated by Abdurrahman Wahid in the presidential elections in the MPR Assembly sessions in November 1999.

\section{References}

[1] M. Ottaway, Angola's Failed Elections, in Krihna Kumar, ed. Post-Conflict Elections, Democratization and International Assistance. Boulder: Lynne Rienner Publisher, 1998.

[2] T. Sisk, Power Sharing and International Mediation in Ethnic Conflict. Boulder: Lynne Rienner, 1998.

[3] J. S. Dunn, The East Timor Affairs: From Civil War to Invasion by Indonesia. Canberra: Australian National University, 1986.

[4] A. Schwarz, A Nation in Waiting: Indonesia's search for Stability, Boulder. C.O: Westview, 2001.

[5] J. G. Taylor, Indonesia's Forgotten War: The Hidden History of East Timor. London: Zed Books, 
1991.

[6] D. Greenlees, Deliverance: The Inside Story of East Timor's Fight for Freedom. Sydney: Alan \& Unwin, 2002.

[7] P. Chalk, Australian Foreign and Defense Policy in the Wake of 1999-2000 East Timor Intervention. Santa Monica: National Security Research Division, 2001.

[8] B. Singh, East Timor, Indonesia and the World. Singapore: Institute for South East Asian Studies (ISEAS), 1997.

[9] L. Sabastian and A. L. Smith, "The East Timor Crisis: A test case for Humanitarian Intervention," J. Southeast Asian Stud. Singapore, 2001.

[10] W. Maley, "Australia and the East Timor Crisis: Some Critical Comments," Aust. J. Int. Aff., p. 54, 2000.

[11] J. Nevins, “The Making of 'Ground Zero' in East Timor,” Asian Survey, 2002.

[12] D. McGraw, "Idealism and Realism in the Foreign Policy of the Forth Labor Government: The Case of New Zealand," Political Science, 2002.

[13] I. Martin, The United Nations, the Ballot, and International Intervention, Boulder. CO: Reinner, 2001.

[14] S. Douglas, "Bitter Flowers, Sweet Flowers: Indonesian East Timor and the World Community," $J$. Asian Stud., vol. 4, p. 61, 2002.

[15] P. J. Eldridge, The Politics of Human Rights in Southeast Asia. London and Singapore: Routledge, 2002.

[16] S. Downie, The UN Mission in East Timor: Comparison with Cambodia, in Damien Kingsbury (ed.), Guns and Ballot Boxes: East Timor's Vote for Independence. Clayton: Monash Asia Institute, 2000.

[17] H. Van Klinken, Taking the Risk, Paying the Price: East Timorese Vote in Ermera, In Richard Tanter and Stephen Salom Bitter Flowers, Sweet Flowers: Indonesian East Timor and the World Community. New York: Littlefield Publisher, 2000.

[18] P. Bartu, The Militia, the Military, and the People of Bobonaro, in Richard Tanter and Stephen Salom, Bitter Flowers, Sweet Flowers: Indonesian East Timor and the World Community. New York: Littlefield Publisher, 2000.

[19] A. Rosser, The Politics of Economic Liberalization in Indonesia. London: Corzon Press, 2001.

[20] A. Budiman, "Indonesia: Trials for President Wahid," ISEAS J. Southeast Asian Stud. Singapore, 2001.

[21] V. Hadiz, The Economic Democracy Debate", in I. Chalmers (ed), The Politic of Economic Development in Indonesia: Contending Perspectives. London: Routledge, 1997. 